\title{
AS CONCESSÕES E AUTORIZAÇÕES PETROLÍFERAS E O PODER NORMATIVO DA ANP
}

AleXandre Santos de ARagão*

I - Introdução. II - Panorama no Ordenamento Jurídico Brasileiro. III - As Concessões Petrolíferas. IV - As Autorizaçōes no Setor Petroleiro. $V$ - As Relações de Sujeição Especial no Direito do Petróleo. VI Extensão e Limites dos Poderes Normativos da ANP. VII - Conclusões.

\section{I-Introdução}

O setor do petróleo foi uma das áreas mais atingidas pela chamada reforma do Estado brasileiro. A liberalização de um setor que tradicionalmente é permeado de preocupações nacionalistas e estratégicas, tendo ficado nas mãos de apenas uma empresa pública por décadas, não poderia se dar sem algumas perplexidades e percalços jurídicos, dificuldades estas potencializadas pelo ineditismo do modelo adotado em relação aos demais países que viveram o mesmo momento de abertura do setor: no Brasil, a empresa pública antes exclusiva continuou a existir, sendo criada concomitantemente uma agência reguladora, figura por si só eivada de controvérsias, para regular o setor, para assinar contratos de exploração e produção, emitir autorizações etc.

Estas perplexidades, como não poderia deixar de ser, logo se manifestaram no cotidiano da indústria do petróleo, que passou a lidar com instrumentos de regulação

* Mestre em Direito Público pela U.E.R.J. Professor contratado de Direito Administrativo e da disciplina eletiva "Agências Reguladoras" da Universidade do Estado do Rio de Janeiro - U.E.R.J. Professor da Pós Graduação em Direito Econômico Internacional da PUC/RJ e da Pós Graduação em Direito da Administração Pública da UFF. Membro das Comissões de Direito Administrativo e de Direito Constitucional do Instituto dos Advogados Brasileiros - IAB (alexaragao@netyet.com.br). 
estatal até então desconhecidos ou pouco utilizados, além das peculiaridades já próprias do Direito do Petróleo. ${ }^{1}$

Os legítimos interesses dos investidores merecem proteção, inclusive pelos altos riscos e elevados montantes que envolvem a atividade do petróleo. Todavia, este desiderato, para que tenha êxito, não pode desconsiderar os interesses estratégicos que foram acolhidos pelo Legislador e pelo Constituinte; o fato da atividade petrolífera, apesar de indubitavelmente constituir uma atividade econômica, continuar sendo um monopólio estatal; e as mudanças que há décadas vêm se consolidando no Direito Administrativo como um todo.

Cabe, neste sentido, trazer à baila a advertência de CARLOS ARI SUNDFELD de que a Constituição Federal não dá uma disciplina acabada para os diversos serviços públicos e atividades econômicas do Estado, deixando ao Legislador um campo bastante largo de conformação. Sendo assim, o estudo da matéria deve mais ter em vista a "legislação de regência" de cada uma destas atividades do que "recorrer-se acriticamente de lições doutrinárias (umas, velhíssimas e desatualizadas; outras, copiadas sem reflexão de livros estrangeiros, muitas vezes mal-lidos; algumas ditadas por vinculações econômicas, partidárias ou pessoais), tentando encaixá-las à força na realidade, sem o menor respeito ao Direito Positivo vigente". ${ }^{2}$

É sob esta perspectiva que, por exemplo, hoje é muito mais profícua a elaboração científica do direito dos investidores participarem da elaboração dos regulamentos editados pela Agência Nacional do Petróleo - ANP, do que o repasse desgastado de teses oitocentistas do Princípio da Legalidade, que só cabem em alguns livros de doutrina menos atualizados e que, de toda sorte, são totalmente irrealistas na vida prática institucional, não apenas do Brasil, mas de todos os países ocidentais. ${ }^{3}$

Elegemos como objeto do presente estudo o poder normativo da ANP, não apenas em razão da sua riqueza teórica, como pela grande importância prática que possui, vez que já não são poucas as normas regulamentares ou contratuais emitidas por esta autarquia que vêm causando dúvidas quanto à sua legalidade.

Partiremos, na busca do esclarecimento da matéria, da análise de algumas premissas imprescindíveis para o seu deslinde, começando pela colocação da ordem econômica na Constituição de 1988 com as reformas que lhe sucederam, tratando inclusive da crucial distinção entre atividade econômica e serviço público, e pelas linhas gerais da Lei do Petróleo (Tópico II).

Passaremos então à análise da natureza jurídica das concessões e autorizações no setor do petróleo, tema de grande importância para a determinação das prerroga-

1 Marilda Rosado define o Direito do Petróleo como sendo "um conjunto de temas e questões do campo minerário, que, pela especificidade de sua economia, amplitude e complexidade de seus efeitos, exige delimitação de conteúdo e fixação de um marco de referência metodológico" (As "Joint Ventures" na Indústria do Petróleo, Ed. Renovar, Rio de Janeiro, 1997, p. 05).

2 A Regulação de Preços e Tarifas dos Serviços de Telecomunicações, na obra coletiva Direito Administrativo Econômico, coordenada pelo próprio Carlos Ari Sundfeld, Ed. Malheiros, São Paulo, 2000 , p. 318.

3 O tema será tratado especificamente no Tópico VI. 
tivas e do poder normativo que a Administração Publica possui no setor (Tópicos III a V).

Após fixadas estas premissas, adentraremos, então, na questão específica do poder normativo da ANP (Tópico VI).

\section{II - Panorama do ordenamento jurídico brasileiro}

A Constituição Brasileira, como constituição compromissória, não poderia deixar de refletir o persistente conflito entre público e privado; entre o livre caminhar da economia e a intervenção estatal; entre os interesses individuais e os coletivos.

Tanto é assim, que as reformas que sucederam à promulgação da Constituição de 1988 tiveram como um dos seus principais focos justamente o Direito Econômico. ${ }^{4}$ Vejamos, portanto, como este se encontra balizado constitucionalmente.

Ao contrário do que ocorre em outros direito positivos, a nossa Constituição estabelece uma nítida distinção entre serviço público ${ }^{5}$ e atividade econômica. $\mathrm{Na}$ verdade, contudo, não podemos torcer a realidade a ponto de sustentar que os serviços públicos não sejam atividades econômicas. Os serviços públicos são atividades econômicas qualificadas como tal, qualificação esta que visa a permitir a prestação direta pelo Estado ou uma forte regulação e ingerência estatal na atividade quando gerida por particulares delegatários. O serviço público revela-se, então, como uma das mais intensas formas de intervenção do Estado na economia.

É desta forma que EROS ROBERTO GRAU considera que a Constituição brasileira de 1988 subdividiu a atividade econômica lato sensu em serviço público e atividade econômica stricto sensu. ${ }^{6}$ Tanto é assim, que o art. 175 , que disciplina a prestação dos serviços públicos pelo próprio Estado ou por concessionários e permissionários privados, está contido no Capítulo destinado aos "Princípios Gerais da Atividade Econômica".

4 As reformas à Constituiçāo de 1988 não chegaram a alterar a classificação das diversas modalidades de regulação estatal da economia, atribuindo, contudo, maior relevo a algumas em detrimento de outras, sem retirar do Texto Maior qualquer uma delas. Em sua maior parte, as reformas permitiram que determinados serviços públicos, que só podiam ser prestados indiretamente por empresas da Administração Indireta, passassem a ser prestados por delegatários privados.

5 Naturalmente que nāo estão incluídas em nosso conceito de serviço público as funçōes públicas soberanas, indelegáveis, como a defesa nacional, a tributação etc. (Ramón Parada, Derecho Administrativo, I, Ed. Marcial Pons, Madrid, $11^{\star}$ ed., 1999, pp. 473/4). Seguindo a melhor doutrina, nosso conceito também não contempla "as atividades que não correspondam a uma específica prestação aos usuários, como por exemplo, as obras públicas" (Elio Casetta, Manuale di Diritto Amministrativo, Ed. Giuffrè, Milão, 2000, p. 605).

6 Eros Roberto Grau, A Ordem Econômica na Constituição de 1988, Ed. Malheiros, São Paulo, $4^{4}$ ed., 1998, pp. 137/9. Alguns autores utilizam a expressão "serviços públicos econômicos" ou "industriais" para denominar as atividades econômicas stricto sensu exploradas pelo Estado (v.g. Charles Celier, Droit Public et Vie Économique, PUF, Paris, 1949, p. 136). Preferimos, no entanto, não fazer uso destas expressões para não misturar os conceitos de atividade econômica (em sentido estrito) explorada pelo Estado e os serviços públicos propriamente ditos. 
Note-se que o objetivo da publicatio há de ser o atendimento direto de necessidades ou utilidades públicas, não o interesse fiscal ou estratégico do Estado, hipóteses em que estaríamos diante de atividades econômicas stricto sensu, que só podem ser monopolizadas pelo Estado nos casos taxativamente estabelecidos na Constituição, e que, ainda que em regime de concorrência com a iniciativa privada, só podem ser por ele exploradas se atendidos os requisitos do caput do art. $173 \mathrm{da}$ Constituição Federal. ${ }^{7}$

Uma das mais objetivas distinções entre atividades econômicas stricto sensu e os serviços públicos foi elaborada por JOSÉ MARIA SOUVIRÓN MORENILLA, que afirma que "uma coisa é a atuação empresarial do Estado, desenvolvida com objetivos de rentabilidade econômica e conforme o mercado, e outra é - ou deveria ser - a atividade "de não-mercado" ou de serviço público. Esta se define porque, a partir dos princípios de universalidade e de igualdade que a preside, se dirige à satisfação de uma necessidade coletiva com objetivos de justiça e de solidariedade social, prevalentes, em todo caso, sobre os critérios econômicos de rentabilidade na exploração do serviço". ${ }^{8}$

RAMÓN PARADA também denota que a atuação econômica (stricto sensu) do Estado não se funda na idéia de essencialidade dos serviços, mas no mais amplo e difuso conceito de interesse público, no qual pode ser incluída qualquer atividade de produção industrial ou de serviços econômicos que, de uma forma ou outra, beneficie os habitantes de determinado local, ainda que apenas para lhes proporcionar emprego, ou mais simplesmente para obter recursos para serem destinados a outras atividades do Poder Público etc. ${ }^{9}$

O interesse do Estado nestes casos, afirma GASPAR ARIÑO ORTIZ, "não é um interesse de utilidade do público, mas um interesse econômico global" . ${ }^{10}$ Tanto nos serviços públicos como nas atividades econômicas o Estado busca a realização de finalidades públicas, que, todavia, são de espécies muito diferentes: “na gestão econômica não há uma finalidade de serviço ao público, isto é, aos cidadãos individualmente considerados, mas uma finalidade de ordenação econômica, de confor-

7 Para uma específica análise da aplicação do Princípio da Subsidiariedade sobre a exploração de atividades econômicas pelo Estado, admissivel apenas nos casos de falha do mercado, ver Laurent Richer, Service Public et Interêt Privé, constante dos Archives de Philosophie du Droit, Tomo 41 - Le Privé et le Public, Ed. Sirey, Paris, 1997, p. 295.

8 La Actividad de la Administración y el Servicio Público, Ed. Colmares, Granada, 1998, p. 574. 9 Derecho Administrativo, Tomo I, Ed. Marcial Pons, Madrid, $11^{2}$ ed., 1999, p. 478. "A atividade econômica desenvolvida pelo Estado também apresenta interesse público, só que subjetivo, na medida em que depende da valorização da Administração; nāo traz em si mesma o interesse público; mas se lhe atribui um interesse público" (Roberto Ribeiro Bazilli, Serviços Públicos e Atividades Econômicas na Constituição de 1988, RDA, 197/15-6). Caso muito comum foi a transferência para o Estado de grandes indústrias como forma de evitar o encerramento das suas atividades (ampliar em Maria Alessandra Stefanelli, La Tutela dell'Utente di Publici Servici, Ed. CEDAM, Padova, 1994, p. 68).

10 Gaspar Ariño Ortiz, Principios de Derecho Público Económico, Ed. Comares e Fundación de Estudios de Regulación, Granada, 1999, p. 241. 
mação social, de serviço nacional, isto é, de promoção econômico-social da nação considerada em seu conjunto"."

Além dos arts. $175,25, \S 2^{\circ}$ e $30, \mathrm{~V}$, a Constituição também prevê no art. 21 a prestação de serviços públicos pela União, mas, desta feita, não apenas diretamente, por concessão ou por permissão, mas também mediante autorização: art. 21, incisos $\mathrm{X}$ (postal e correio), XI (telecomunicações) e XII, " $a$ " a " $\mathrm{f}$ " (serviços de radiodifusão sonora e de sons e imagens; serviços e instalações de energia elétrica e o aproveitamento energético dos cursos de água; a navegação aérea, aeroespacial e a infraestrutura aeroportuária; os serviços de transporte ferroviário e aquaviário; os serviços de transporte rodoviário interestadual e internacional de passageiros; os portos marítimos, fluviais e lacustres) e XIII (nucleares).

Os princípios das atividades econômicas fixados no art. 170 devem inspirar a exploração de todas as atividades econômicas, sejam elas serviços públicos ou atividades econômicas stricto sensu.

Em relação à atividade econômica stricto sensu, a Constituição estabelece o monopólio em favor da União (arts. 20, 176 e 177) de uma série de bens e atividades a eles correlatas, com destaque para os bens minerais, inclusive o petróleo e seus derivados.

A exploração pelo Estado de outras atividades econômicas stricto sensu, isto é, além daquelas que são objeto de monopólio, é permitida apenas em regime de concorrência com a iniciativa privada e desde que seja necessária aos imperativos da segurança nacional ou ao atendimento de relevante interesse coletivo (art. 173).

Vige para as atividades econômicas stricto sensu não monopolizadas, participe delas o Poder público ou não, o princípio da liberdade de iniciativa, observadas as regras de polícia econômica geral que as conforme aos princípios e valores fundamentais da República Federativa do Brasil (arts. $1^{\circ}$ e $3^{\circ}$ ) e aos princípios setoriais da ordem econômica (art. 170), exigida, quando for o caso, autorização prévia para o seu exercício (art. art. 170, parágrafo único).

Especificamente sobre o petróleo, a Constituição Federal é pródiga, dispondo sobre: a) a titularidade federal sobre os principais bens envolvidos nesta indústria - os recursos minerais; b) a competência da União para legislar sobre energia e recursos minerais (art. 22, IV e XII); c) a competência dos Estados para prestar os serviços de distribuição de gás canalizado (art. $25, \S 2^{\circ}$ ); d) o monopólio federal sobre as atividades básicas da indústria do petróleo (art. 177); e) as condições da atuação pública e privada no setor (art. $20, \S 1^{\circ}, 176$ e 177); e f) a previsão de um órgão regulador (art. $177, \S 2^{\circ}$, III). ${ }^{12}$

$\mathrm{O}$ art. 177 da Constituição Federal estabelece como monopólio da União a pesquisa; a lavra; o refino do petróleo, nacional ou estrangeiro; a importação; exportação e o transporte marítimo ou por dutos do petróleo e dos seus derivados.

11 Gaspar Ariño Ortiz, Principios de Derecho Público Económico, Ed. Comares e Fundación de Estudios de Regulación, Granada, 1999, p. 494.

12 Regime Jurídico do Setor Petrolífero, p. 386, de Carlos Ari Sundfeld, constante da obra coletiva coordenada pelo próprio, Direito Administrativo Econômico, Ed. Malheiros, São Paulo, 2000. 
Note-se que há atividades da indústria do petróleo, como o transporte que não seja marítimo ou por dutos, assim como a distribuição e a revenda, que não constituem monopólios da União, sendo atividades da iniciativa privada, sujeitas, no entanto, à regulação estatal na forma dos arts. 170 e 174 da Constituição Federal.

Regulamentando o art. 177, CF foi editada a Lei $n^{\circ} 9.478 / 97$, conhecida como a Lei do Petróleo, que estabeleceu a política energética nacional, disciplinou as atividades da indústria do petróleo tal como definida no seu art. $6^{\circ}$, XIX, criou o Conselho Nacional de Política Energética e a Agência Nacional do Petróleo - ANP, cabendo a esta a implementação da política traçada pelo primeiro (art. $8^{\circ}, \mathrm{I}$ ).

As atividades petrolíferas foram pela Lei do Petróleo "declaradas de utilidade pública. Assim, elas têm o ônus público de deverem ser prestadas em benefício da população, no sentido de que o explorador destas atividades tem alguns ônus para com a população e para com o Estado". ${ }^{13}$

$\mathrm{O}$ art. $5^{\circ}$ da Lei do Petróleo dispõe que a faculdade conferida pelo art. $177, \S$ $1^{\circ}$, da Constituição Federal, ou seja, a contratação de particulares ou de empresas estatais para a exploração das atividades petrolíferas monopolizadas pela União, se dará mediante concessão ou autorização.

Para cada espécie ou fase da atividade petrolífera a Lei do Petróleo dá uma disciplina distinta, razão pela qual é de grande relevância distinguirmos: (a) exploração (ou pesquisa), na qual a empresa procura por petróleo em blocos ou áreas pré-delimitadas; (b) produção ou lavra, pela qual o petróleo é extraído da jazida; (c) importação e exportação, sendo que aquela, tal como a produção, concorre para o suprimento interno do produto; $(d)$ refino, processo pelo qual o petróleo deve passar para poder ser utilizado; $(e)$ transporte: para que o petróleo bruto ou seus derivados cheguem aos seus destinos devem ser transportados. "O transporte pode se dar de várias formas. Há os meios fixos, os condutos ( o oleoduto e o gasoduto). Há os meios móveis, sendo os navios os principais"; 14 e $(f)$ distribuição: para que os derivados do petróleo cheguem aos consumidores deve haver "a distribuição de derivados do petróleo, uma espécie de revenda destes derivados no atacado" $;{ }^{15}$ e $(g)$ revenda: "os consumidores finais são atingidos pela atividade de revenda de derivados de petróleo", 16 feita nas maioria das vezes pelos "postos de gasolina".

Apenas as atividades de exploração e produção (letras " $a$ " $e$ " $b$ ") foram submetidas à concessão, tendo sido exigida para as demais (letras " $c$ " $a$ " $g$ ") a prévia autorização.

13 Maria d'Assunção Costa Menezello, Introdução ao Direito do Petróleo e Gás, constante da obra coletiva Direito Administrativo Econômico, coordenada por Carlos Ari Sundfeld, Ed. Malheiros, São Paulo, 2000, p. 382.

14 Carlos Ari Sundfeld, Regime Jurídico do Setor Petrolífero, constante da obra coletiva, coordenada pelo próprio autor, Direito Administrativo Econômico, Ed. Malheiros, São Paulo, 2000, p. 388.

15 Idem.

16 Idem. 
Vê-se que a Lei do Petróleo, considerando menos o monopólio incidente sobre as atividades do setor, e mais a possibilidade de concorrência que cada uma delas pode propiciar, destinou a autorização para as atividades nas quais se dêem as maiores possibilidades de concorrência.

Assim, as atividades não monopolizadas (transporte que não seja marítimo ou por dutos, a distribuição e a revenda) não são sujeitas à prévia concessão, até porque esta, precedida de licitação, pressupõe a limitação do número de operadores, limitação esta que não seria admissível em se tratando de atividade de titularidade da iniciativa privada, sujeita, todavia, a autorização (art. $9^{\circ}$, Lei do Petróleo).

Já as atividades monopolizadas (exploração, produção, importação, exportação, refino, transporte marítimo e por dutos) podem ser sujeitas à concessão ou à autorização. A Lei reservou esta modalidade regulatória para as atividades (monopolizadas) de refino, importação, exportação e transporte marítimo ou por dutos, que não apenas admitem, como, pelo Princípio da Subsidiariedade, demandam, a maior concorrência possível (arts. 53, 56 e 60, Lei do Petróleo).

A concessão foi destinada apenas para a exploração e produção, vez que pressupõem a delimitação espacial, não sendo factível a abertura de concorrência para que todas as empresas interessadas explorassem ao mesmo tempo determinada jazida (art. 23, Lei do Petróleo). Além destas limitações fáticas, concorre para a imposição da prévia concessão para a exploração e produção de petróleo o fato de "envolverem o uso de bem público; portanto, a fruição é um privilégio". ${ }^{17}$

Não estamos a dizer que não deva haver concorrência nestas atividades, mas apenas que esta fica restrita à escolha do concessionário, que, uma vez escolhido, não terá a concorrência de outros concessionários sobre a mesma área.

Observe-se que em relação às atividades petrolíferas monopolizadas, que não são apenas a exploração e produção de petróleo, o $\S 1^{\circ}$ do art. 177 da Constituição Federal alude à contratação de estatais ou de empresas privadas. Não sendo a autorização contrato, mas ato administrativo, poderia o Legislador ter assentido na exploração privada de algumas destas atividades mediante autorização?

Entendemos que sim, ou seja, que, em razão dos princípios da proporcionalidade e subsidiariedade, sempre que atendido o interesse da coletividade, se impõe a adoção da modalidade regulatória menos constritiva, in casu a ordenatio, em detrimento da publicatio. As atividades petrolíferas monopolizadas de refino, importação, exportação e transporte marítimo ou por dutos, podem ser consentidas a um número indeterminado de agentes econômicos privados, o que é consentâneo com o princípio da livre iniciativa, ficando, no entanto, sujeita à ordenação pública autorizativa.

Podemos resumir o exposto pela seguinte tabela: ${ }^{18}$

17 Carlos Ari Sundfeld, Regime Jurídico do Setor Petrolífero, constante da obra coletiva coordenada pelo próprio, Direito Administrativo Econômico, Ed. Malheiros, São Paulo, 2000, p. 395.

18 Cf. Marcello Mello, A Natureza Jurídica dos Contratos de Concessão Firmados entre a União e os Particulares no Setor Petrolífero, mimeo. 


\begin{tabular}{|c|c|c|c|}
\hline Atividade & Petróleo & Gás Natural & $\begin{array}{c}\text { GLP, Gasolinas, Naftas, Querosenes, Oleo } \\
\text { Diesel, Gasóleos, Oleos Combustíveis }\end{array}$ \\
\hline Exploração & Concessão & Concessão & - \\
\hline Produção & Concessão & Concessão & Autorização \\
\hline Transporte & Autorização & Autorização & Autorização \\
\hline Refino & Autorização & Autorização & - \\
\hline Importação & Autorização & Autorização & Autorização \\
\hline Exportação & Autorização & Autorização & Autorização \\
\hline Distribuição & - & $\begin{array}{c}\text { Concessão } \\
\text { dos Estados }\end{array}$ & Autorização \\
\hline
\end{tabular}

Procuraremos nos Tópicos seguintes demonstrar as garantias que as concessões e autorizações petrolíferas dão aos seus titulares, assim como as prerrogativas das quais a ANP dispõe, não apenas no momento da sua elaboração, como ao longo da execução dos respectivos objetos.

\section{III - As concessões petrolíferas}

A Constituição permite que as atividades econômicas petrolíferas monopolizadas pela União sejam, sem quebra do monopólio, exploradas pela iniciativa privada (art. 177, § $1^{\circ}$ ).

Há grande discussão sobre a natureza jurídica dos contratos que dão aos particulares o direito de exploração de monopólios públicos, aí incluídos os que lhes propicia a exploração e produção de petróleo — bem público dominical -, contratos normalmente denominados de concessão de exploração de atividades econômicas ou de bens públicos dominicais monopolizados pela União.

Preliminarmente, há de se destacar que "os bens públicos não são só suscetíveis de uso (ou aproveitamento), mas também de gestão ou exploração econômica por alguém que toma o lugar da pessoa coletiva de direito público. Embora relacionadas com um bem público, o que caracteriza as concessões de exploração do domínio público é a atribuição do direito de exercer uma actividade que a lei reservou para a Administração: o que está em causa não é a utilização do bem, mas a actividade de o explorar ou gerir". 19

Como adverte GASPAR ARIÑO ORTIZ, não podemos inferir da nomenclatura de "concessão" a caracterização da atividade econômica stricto sensu monopolizada como serviço público: “a simples denominação como tal ou a exigência de concessão para determinadas atividades agrícolas, industriais ou comerciais (...) não corresponde necessariamente à existência de um verdadeiro serviço público". ${ }^{20}$

19 Pedro Gonçalves, A Concessão de Serviços Públicos, Ed. Almedina, Coimbra, 1999, p. 93.

20 Gaspar Ariño Ortiz, Principios de Derecho Público Económico, Ed. Comares e Fundación de Estudios de Regulación, Granada, 1999, p. 488. 
O próprio surgimento das concessões tem uma conotação bem mais ampla do que a meramente ligada aos serviços públicos. As concessões advieram da necessidade de conciliação entre os dogmas liberais não-intervencionistas e a urgência do Estado regular com maior intensidade novas atividades (ferrovias, gás, telefonia, eletricidade etc.), de complexidade técnica e de tendências monopolizadoras até então desconhecidas. ${ }^{21}$

Tradicionalmente, os contratos pelos quais a Administração Pública assente no exercício por particulares de atividade econômica monopolizada são denominados de concessões - não de serviços públicos —, mas concessões industriais ou econômicas.

A determinação da natureza jurídica destas concessões - se privada ou pública - não é pacífica: por um lado, como têm por objeto atividade econômica, seriam de Direito Privado; por outro, como dizem respeito a atividades ou bens que, por força da Constituição, são monopolizados pelo Poder Público por razões estratégicas ou fiscais, exigem uma disciplina publicística.

Devemos, todavia, ter em vista que a diferença entre o que é de direito privado e o que é de direito público é cada vez mais relativa, havendo contratos tradicionalmente considerados como de direito público com um sem número de resguardos dos interesses da partes privadas, e contratos de direito privado sujeitos a forte intervenção estatal. ${ }^{22}$

Assim é que ANDRÉ DE LAUBADÈRE, distinguindo as concessões de serviços públicos das concessões industriais, afirmou que, "a despeito desta intervenção do Estado na atividade do particular e da utilização do termo "concessão", este instituto é totalmente diferente da concessão de serviço público: a atividade sobre a qual incide é uma atividade privada, submetida não ao regime de serviço público, mas àquele do direito privado, sob reserva das infiltrações de direito público". ${ }^{23}$

21 Gaspar Ariño Ortiz, afirmou que "a tensão entre a urgência de satisfazer as novas necessidades públicas - exigências de uma sociedade progressivamente urbana e industrial - e as concepções ideológicas liberais imperantes, será resolvida mediante um mecanismo genial: a concessão administrativa. Na concessão, o Estado encontrará uma fórmula que lhe permitirá compatibilizar uma e outra postura; de uma parte, se entenderá que o Estado é titular de tais atividades; o dominus dos serviços públicos; de outra, se entenderá que o Estado não deve geri-los diretamente e se valerá da concessão como fórmula-ponte que o permite dirigir sem gerir. A concessão se configurará assim como uma transferência de funções e tarefas cuja titularidade corresponde primariamente ao Estado, atividades que não eram intrinsecamente públicas, que não faziam parte das finalidades históricas do Estado, de seus fins essenciais, mas que acabaram sendo "publicizadas" (Principios de Derecho Público Económico, Ed. Comares e Fundación de Estudios de Regulación, Granada, 1999, pp. 483/4).

22 No Direito Civil destaca-se a insurgência do Direito Civil Constitucional, cuja construção teórica no Brasil é em grande monta devida a Gustavo Tepedino (entre outros, ver $O$ Código Civil, os chamados microssistemas e a Constituição: premissas para uma reforma legislativa, constante da obra coletiva Problemas de Direito Civil Constitucional, Ed. Renovar, Rio de Janeiro, 2000, coordenada pelo próprio autor citado, pp. 17/54.

23 Manuel de Droit Administratif, Ed. LGDJ, 15² ed., Paris, 1995, p. 289. 
No mesmo sentido pronunciou-se GLADYS VÁSQUEZ FRANCO, valendo-se das lições de VILLAR PALASI: "A maior abrangência e expansão da atividade administrativa do Estado contribuiu para o enriquecimento da idéia concessional. Foi necessária a inclusão neste conceito de novas atividades que não cabem dentro da tradicional concessão de serviço público. Nasce desta forma a moderna concessão industrial. (...) A extensão da atividade da Administração até o campo econômico atribuído inicialmente apenas aos particulares, rompe com a estrutura tradicional" ${ }^{24}$

A nosso ver, tais contratos, como não visam à delegação de serviços públicos, são, em linhas gerais, de Direito Privado, ${ }^{25}$ o que não impede e, ao revés, impõe, que possuam cláusulas de ordem pública e de dirigismo estatal, não apenas quando da sua celebração, como também ao longo da sua execução. ${ }^{26}$

No momento da celebração das concessões, nem há como se falar propriamente em dirigismo, uma vez que o proprietário do bem monopolizado ou o titular exclusivo da atividade monopolizada é o próprio Estado, que pode estabelecer as condições contratuais que, dentro do que a lei permitir, melhor lhe convierem. ${ }^{27}$ Os particulares

24 La Concessión Administrativa de servicio público, Ed. Temis, Bogotá, 1991, p. 50.

25 Toshio Mukai também considera que os contratos de exploração de atividades econômicas monopolizadas são de direito privado (Contrato de Concessão formulado pela Agência nacional do Petróleo - Comentários e Sugestōes, RTDP, 25/82-93). O autor, no entanto, parece entender que por esta razão tais contratos não estão sujeitos a quaisquer influxos publicísticos, o que, como expomos, não ocorre sequer em muitos contratos de direito privado celebrados entre particulares. O autor também, a nosso ver equivocadamente, critica a utilização pela Lei do Petróleo do termo "concessão", olvidando que nem toda concessão é de serviço público, e que há muito a doutrina nacional e estrangeira trata das concessões de atividades econômicas monopolizadas pelo Estado. Em Portugal, por exemplo, se afirma, em lição plenamente afinada com o nosso Direito, que "um dos setores de aplicação desta modalidade concessória é constituído pela atribuição a particulares de poderes de exploraçāo das riquezas naturais que se encontram no território do Estado e que a lei considera propriedade pública (Pedro Gonçalves, $A$ Concessão de Serviços Públicos, Ed. Almedina, Coimbra, 1999, p. 93).

26 Em sentido contrário, mas ainda antes da flexibilização do monopólio estatal do petróleo, entendendo tratar-se de contrato de direito público, Caio Tácito, Permissão de Refino de Petróleo, constante da obra Temas de Direito Público, Ed. Renovar, Rio de Janeiro, 1997, pp. 1.617 a 1.631. Segundo Paulo Valois (A evolução do Monopólio Estatal do Petróleo, Ed. Lumen Juris, Rio de Janeiro, 2000, p. 134), “a doutrina se posiciona das mais variadas formas, desse modo, a quem diga que o referido contrato tem natureza de: concessão de serviços públicos, serviços de utilidade pública, exploração de bem público, acordo de desenvolvimento econômico, de exploração de atividade econômica e até de relação regida pelo Direito Internacional". Sobre o mesmo tema, podemos também trazer o posicionamento de Marcos Juruena Villela Souto (Desestatização; Privatização; Concessões e Terceirizaçōes, Ed. Lumen Juris, Rio de Janeiro, p.127), para quem “o contrato não é de serviço público, obra pública ou direito real de uso. O Direito Internacional já identificou a concessão de petróleo como sui generis. São chamados contratos de Estado, entre Governos e particulares. No mundo todo, usa-se o termo license, aqui traduzido como concessão, que é contrato econômico e não administrativo. O Estado atua como agente econômico (empresário)".

27 Não devemos nos esquecer que, tanto a lei como o contrato, são fontes primárias do Direito. Noutras palavras, os contratos têm a mesma capacidade das leis para criarem direitos e obrigaçōes. 
não são obrigados a celebrar o contrato; será o seu livre consenso que dará força jurídica à concessão.

Ao longo da execução do contrato, também se impõe a atuação regulatória do Poder Público, integrando e interpretando Cláusulas contratuais e, se for o caso, adequando-as à dinâmica da realidade sócio-econômica de acordo com a política pública adotada para o setor pela Lei do Petróleo e pelo Conselho Nacional de Política Energética.

Estas potestades públicas em nada ilidem a natureza privada da concessão industrial de petróleo. No mundo contemporâneo há uma série de contratos de direito privado, muitas vezes sequer celebrados pelo Poder Público, que, em razão do seu estreito liame com os interesses da coletividade, ficam sujeitos a uma constante regulação estatal (ex.: os contratos dos planos de saúde, os contratos educacionais etc.).

Ademais, "aos poucos se tomou consciência de que os contratos administrativos não tinham um carácter tão "exorbitante" quanto num primeiro momento se tinha pensado. Simultaneamente, por um processo inverso, verificou-se a percepção da necessidade de sujeitar os contratos jurídico-privados da Administração a determinadas vinculações de direito público. Trata-se, assim, do segundo termo da dicotomia "desmistificação do contrato administrativo/publicização do contrato jurídico-privado", que vai ter como principal consequiência a uniformização do regime jurídico aplicável a todos os contratos da Administração". ${ }^{28}$

Note-se que a própria constitucionalidade da regulação estatal de atividades econômicas privadas já foi diversas vezes afirmada pelo Supremo Tribunal Federal - STF. Em uma destas decisões, o Ministro SEPÚLVEDA PERTENCE, tratando da constitucionalidade do controle estatal sobre as mensalidades escolares, afirmou:

"Senhor Presidente, temos, ao menos desde 1934, e marcadamente no texto de 88, uma típica Constituição compromissória, como de resto, sói serem quase todas as Constituições contemporâneas. De tal modo que é sempre arbitrário que a afirmação de um dos valores, de um dos vetores axiológicos do projeto de sociedade veiculado pela Constituição, se faça com a abstração de outros valores, de outros vetores axiológicos... Um instrumento constitucional de concretização desta função permanente de ponderação de valores que, em termos absolutos, se contradiriam, Senhor Presidente, é precisamente, na ordem econômica, a competência do Estado para intervir como agente normativo e regulador da atividade econômica". ${ }^{29}$

A Ementa do acórdão foi assim redigida:

28 Maria João Estorninho, Réquiem pelo Contrato Administrativo, Ed. Almedina, Coimbra, 1990, p. 151.

29 ADIN n³ 319-DF, RTJ, 149:666/692. 
"Em face da atual Constituição, para conciliar o fundamento da livre iniciativa e do princípio da livre concorrência com os da defesa do consumidor e da redução das desigualdades sociais, em conformidade com os ditames da justiça social, pode o Estado, por via legislativa, regular a política de preços de bens e serviços, abusivo que é o poder econômico que visa o aumento arbitrário de lucros. Logo, determinada lei não é inconstitucional pelo só fato de dispor sobre critérios de reajuste de mensalidades das escolas particulares". ${ }^{30}$

Ora, se é assim para as atividades econômicas da iniciativa privada, a fortiori deve ser afirmado o poder regulatório estatal sobre as atividades econômicas de titularidade pública quando exploradas por particulares, desde que, naturalmente, esta regulação desenvolva-se nos lindes da legislação pertinente à atividade monopolizada, das suas normas regulamentadoras e das cláusulas do contrato de concessão.

Vemos com isto, que, a rigor, o que importa não é a natureza privada ou pública das concessões de exploração de atividades econômicas monopolizadas pelo Estado, mas sim os poderes concretamente conferidos pelo ordenamento jurídico à Administração Pública. Assim, por um lado, não há um poder exorbitante genérico da Administração sobre os contratos ditos "de direito público", e, por outro, os contratos "de direito privado" celebrados pelo Estado ficam embebidos das cláusulas exorbitantes que a lei lhes atribuir.

Em obra já considerada como um dos mais recentes clássicos do Direito Público, MARIA JOÃO ESTORNINHO ${ }^{31}$ observa que "a idéia da "exorbitância dos poderes que a Administração é dotada nos contratos que celebra foi, em grande medida, devida ao facto de que o Direito Privado utilizado como ponto de comparação ser ainda, na época, o Direito clássico de inspiração novecentista. Esse direito contratual do séc. XIX caracterizava-se por partir de premissas individualistas, tais como a liberdade contratual e a igualdade jurídica das partes. Entendidas de uma forma absoluta, essas premissas giravam em torno da idéia fundamental de autonomia privada e eram, de facto, incompatíveis com situações de domínio de uma das partes num contrato. À luz desses cânones tradicionais do Direito contratual privado era, na realidade, impensável que uma das partes pudesse ditar a seu bel-prazer a interpretação das cláusulas contratuais ou qualquer modificação à sua redação inicial.

Quão longe estão essas concepções iniciais acerca da autonomia privada! Ao longo do séc. XX, a disciplina dos contratos sofreu as mais profundas transformações, verificando-se quer o alargamento da intervenção do Estado na própria área contratual quer, por outro lado, o aparecimento de novos contratos e de situações de desequilíbrio entre as partes e de predomínio de uma delas.

Cresceu o número de normas imperativas destinadas a proteger a situação da parte considerada mais fraca e, por outro lado, destinadas a tutelar valores que passaram a ser encarados como sendo interesses de ordem pública. O contrato deixa

30 Idem.

31 Réquiem pelo Contrato Administrativo, Ed. Almedina, Coimbra, 1990, pp. 140 e 141, grifamos. 
de ser considerado apenas como expressão da autonomia privada e passa a ser visto também como "um instrumento de cooperação entre as pessoas, no plano dos valores que o Direito é chamado a servir". Nesta medida, a lei passa a colaborar activa e permanentemente com a vontade das partes podendo mesmo afirmar-se que $a$ vontade dos contraentes e a lei passam a integrar, em estreita união, "o todo incindivel que é a disciplina do contrato".

Neste contexto, os poderes contratuais da Administração Pública na elaboração e no desenvolvimento das concessões petrolíferas não diferem essencialmente das ingerências públicas em muitos contratos celebrados entre particulares. A "exorbitância de poderes" aqui considerada não existe em relação à noção em si de contrato de direito privado, sendo "exorbitantes" apenas se comparadas à sua concepção novecentista. $O$ fator determinante será a disciplina legal reguladora de cada contrato, não sua a classificação abstrata e estéril como "público" ou "privado". 32

Valem ser citadas as lições de CARLOS ARI SUNFELD, que, por tão óbvias, já deveriam ser um truísmo na doutrina administrativa nacional: "simplesmente nāo faz sentido, na atualidade, supor que as respostas a muitas dúvidas cruciais (ex.: Pode-se negar o serviço a consumidor inadimplente? Pode haver liberdade para o próprio prestador determinar seu preço? Há responsabilidade do Estado em virtude dos danos gerados pela execução de serviços por empresa autorizada?) serão encontradas por meio da operação simplista de identificar o caráter público ou privado do serviço em causa, que teria o mágico condão de determinar a aplicabilidade de um regime jurídico geral. Daí a mudança total de enfoque. Não se cuida mais de discutir o caráter público ou privado de certo serviço, mas sim de identificar como ele é regulado pelo Estado no tocante ao aspecto tal ou qual". ${ }^{33}$

FRANCISCO LÓPEZ MENUDO, tratando especificamente das concessões de exploração econômica de bens públicos ensina com maestria que, "certamente, o ius variandi da Administração é figura plenamente admitida na atualidade, a margem de qualquer consideração dogmática sobre a natureza unilateral ou contratual da concessão e com abstração de se ela é uma concessão de domínio público o de gestão de um serviço público. $O$ centro de gravidade da questão não se encontra na índole ou forma destes títulos, mas no interesse público, cuja devida satisfação no pode ficar obstruída por apriorismos dogmáticos nem por interesses privatistas. Vistas assim as coisas, se reforça a idéia de que o concessionário - qualquer concessionário — mão é, em essência, a «parte» de una relação contratual em pé de igualdade, mas sim o sujeito passivo de uma «relação especial de sujeição», o que implica dizer que junto a direitos subjetivos certos que pode fazer valer, o concessionário se acha em una básica situação de submissão derivada não ex contractu, mas do marco jurídico geral em que se insere, marco este que reconhece à Administração uma clara posição

32 Como se sabe, para regular a exploração das jazidas de petróleo da Uniāo por particulares ou estatais, foi criada a Agência Nacional do Petróleo - ANP, cujos poderes regulatórios são determinados precipuamente pelo conteúdo da sua respectiva lei criadora (Lei ${ }^{\circ}{ }^{\circ}$.478/97).

33 Introdução às Agências Reguladoras, constante da obra coletiva Direito Administrativo Econômico, coordenada por Carlos Ari Sundfeld, Ed. Malheiros, São Paulo, 2000, p. 03, grifos nossos). 
de superioridade compreensiva de uma gama de poderes - alguns de construção jurisprudencial - cujas manifestações concretas refletem-se claramente na legislação atual. Nos referimos aos poderes de direção, inspeção e controle; poder de interpretação unilateral do contrato; e muito especialmente, no que nos interessa, o chamado ius variandi, principio expressivo da sujeição das concessões ao interesse geral e ao poder modificador da Administração, sem prejuízo, é claro, dos limites legais e dos direitos dos quais os interessados forem titulares ". 34

Estas assertivas doutrinárias mereceram expressa acolhida em nosso Direito positivo, especificamente no inciso I do $\S 3^{\circ}$ do art. 62 da Lei $n^{\circ} 8.666 / 93,{ }^{35}$ que expressamente fixou o princípio da aplicação das cláusulas exorbitantes aos contratos ("predominantemente") de direito privado celebrados pela Administração Pública, dispositivo que, naturalmente, deve ser combinado com a legislação específica do setor do petróleo.

Feita a necessária relativização e desmistificação da relevância da caracterização do contrato de concessão celebrado pela ANP como público ou privado, devemos centrar nossa atenção na disciplina legal setorialmente atribuída à exploração e produção de petróleo, que contempla uma série de poderes da ANP sobre as atividades econômicas em questão que, não nos olvidemos, são de titularidade exclusiva da União.

Sendo assim a análise deve se focar sobre os poderes regulatórios conferidos pela Lei do Petróleo à ANP, que podem ser classificados grosso modo como sendo os seguintes: (a) poderes regulamentares de fixar unilateralmente as normas pelas quais devem os concessionários desenvolver as suas atividades; (b) poderes normativo-contratuais, exercidos quando da elaboração dos editais de licitação e dos respectivos contratos de concessão; (c) poder regulamentar de interpretação e integração das normas contratuais.

Como todos os poderes administrativos, os poderes da ANP acima enumerados também são limitados. Os seus exatos contornos serão objeto do Tópico VI infra.

\section{IV - As autorizações no setor petroleiro}

Ao tratar da matéria objeto do presente Tópico devemos ter em mente que "as atividades que envolvem apenas interesses privados são, no mundo contemporâneo, pouquíssimas. Entre estas e as atividades objetivamente públicas se situam atividades que envolvem ao mesmo tempo interesses públicos e privados. Elas são "privadas"

34 La concesión de aguas públicas y sus posibles modificaciones, Revista Española de Derecho Administrativo, vol. 73).

35 Lei $n^{\circ} 8.666 / 93$, art. $62, \S 3^{\circ}$ - Aplica-se o disposto nos arts. 55 e 58 a 61 desta Lei e demais normas gerais, no que couber: I - aos contratos de seguro, de financiamento, de locação em que o Poder Público seja locatário, e aos demais cujo conteúdo seja regido, predominantemente, por norma de direito privado. 
em sentido subjetivo, isto é, no sentido de que o ordenamento jurídico deixa as respectivas iniciativas aos particulares; objetivamente, ao contrário, podem apresentar pertinência, mais ou menos ampla, ao interesse público". ${ }^{36}$

As atividades da indústria do petróleo sujeitas à autorização integram esta espécie de atividade econômica de especial interesse público.

Note-se que não estamos aludindo apenas aos reflexos que toda atividade privada pode ter para a coletividade, reflexos estes que são objeto do poder de polícia da saúde, da segurança etc. A ligação com o interesse público das atividades petrolíferas sujeitas à autorização não se dá apenas neste sentido negativo - de não agredirem ao interesse público —, mas também em sentido positivo - de atenderem a política pública setorial do petróleo.

EDUARDO GARCÍA DE ENTERRÍA e TOMÁS-RAMÓN FERNÁNDEZ chamam a atenção para o fato de que "o conceito de autorização em sentido estrito que chegou até nós se formou no final do século passado (...). A crise do esquema tradicional se deu mais agudamente a partir do momento em que, ultrapassando o campo próprio da ordem pública, em sua tríplice dimensão compreensiva da tranquuilidade, segurança e salubridade, em função da qual foi pensado dito esquema, $a$ autorização foi transplantada ao complexo campo das atividades econômicas, nas quais desempenha um papel que não se reduz ao simples controle negativo do exercício de direitos, mas que se estende à própria regulação do mercado, com o explícito propósito de orientar e conformar positivamente a atividade autorizada no sentido da realização de uns objetivos previamente programados ou ao menos implicitamente definidos nas normas aplicáveis". ${ }^{37}$

Distinguindo as autorizações de operação das autorizações de funcionamento, ora abordadas, JUAN CARLOS CASSAGNE afirma que "a diferença não é puramente conceitual ou didática, mas se projeta sobre as relações entre o particular e a administração. Nas autorizações de operação, o poder desta última se esgota com a emissão do ato, não dando, salvo previsão expressa em contrário, origem a nenhum vínculo posterior com o administrado. Ao revés, nas autorizações de funcionamento há uma vinculação permanente com a administração, com a finalidade de tutelar o interesse público, admitindo-se - tanto na doutrina como na jurisprudência espanhola - a possibilidade de modificação do conteúdo da autorização para adaptá-lo, constantemente, a dita finalidade, durante todo o tempo em que a atividade autorizada seja exercida". 38

"Enquanto a ordem pública clássica visava à defesa das instituições essenciais da sociedade contra as agressões que poderiam sofrer dos indivíduos, a ordem pública econômica não se limita a estabelecer restrições; ela também comanda, para tornar as atividades econômicas mais eqüitativas, ou para melhor as ordenar em consonância

36 Massimo Severo Giannini, Diritto Amministrativo, Ed. Giuffrè, Milão, 3* ed., 1993, pp. $21 / 2$.

37 Curso de Derecho Administrativo, Tomo II, Ed. Civitas, 6* ed., Madrid, 1999, pp. 133/4, grifamos.

38 La Intervención Administrativa, Ed. Albeledo-Perrot, Buenos Aires, 2 ed., p. 81, grifamos. 
com o interesse geral: segundo uma distinção comumente realizada, a ordem pública econômica pode ser, portanto, de proteção ou de direção". ${ }^{39}$

Para GLADYS VÁSQUEZ FRANCO ${ }^{40}$ esta nova geração de autorizações "propicia o surgimento de uma relação de caráter continuado entre a entidade autorizante e o sujeito autorizado, o que se dá em razão da importância da atividade autorizada, cuja realização se estende no tempo e compromete interesses públicos e gerais".

Todavia, na regulação destas atividades econômicas de interesse geral, das quais as atividades petrolíferas autorizadas são exemplo, o Poder Público deve se limitar a expedir as normas que digam respeito ao interesse coletivo definido em lei, não podendo se imiscuir em assuntos intestinos das empresas, mesmo que atinentes a outros interesses públicos não contemplados na Lei do setor (ex.: ao regular a revenda de derivados de petróleo, pode estabelecer a tarifa, o meio de identificação, os requisitos de segurança e de proteção ao consumidor etc., mas não pode impor a obrigação das bombas utilizadas serem nacionais para fomentar a produção doméstica de tais máquinas).

E mais, em relação às atividades petrolíferas não monopolizadas não poderá o Poder Público impor regulação que faça a autorização equivaler à concessão, a uma publicatio, ou seja, não poderá conferir poderes ao Poder autorizante correspondentes aos que existiriam se a atividade fosse monopolizada pelo Estado, sob pena de incidir em fraude à Constituição. ${ }^{41} \mathrm{O}$ Legislador não pode criar um monopólio público pela via transversa da autorização ordenadora ou funcional.

A Lei do Petróleo, ao contrário do que faz em relação às concessões, às quais dedica uma série de dispositivos, disciplina pouquíssimo as atividades petrolíferas sujeitas a autorização, deixando, com isto, uma larga margem regulatória, normativa, à ANP, que possui amplos poderes para, observados os limites que abordaremos no Tópico VI, fixar os termos das autorizações e regulamentar a forma com que as atividades autorizadas deverão se desenvolver para atender à política pública estabelecida para o setor. ${ }^{42}$

Tradicionalmente, as autorizações administrativas são qualificadas como atos administrativos discricionários e precários. Entendemos que dada a vagueza da Lei em relação às autorizações petrolíferas o seu caráter discricionário é inegável, caráter este que não pressupõe necessariamente a precariedade, que é excluída, por exemplo,

39 Dominique Bureau, la Réglementation de l'Économie, constante dos Archives de Philosophie du Droit, Tomo 41 - Le Privé et le Public, Ed. Sirey, Paris, 1997, p. 327.

40 La Concessión Administrativa de Servicio Público, Ed. Temis, Bogotá, 1991, pp. 45-7.

41 Alguns autores chegam a se referir a "concessões encobertas" (Pedro Gonçalves, $A$ Concessão de Serviços Públicos, Ed. Almedina, Coimbra, 1999, p. 21 ).

42 A Lei do Petróleo não especifica de antemão os requisitos necessários à obtençãa das licenças, aludindo apenas à obrigatoriedade da sua prévia emissão para que as atividades de importação, exportação, refino, transporte, distribuição e revenda de petróleo e dos seus derivados possam ser exploradas. 
em todas as autorizações por prazo determinado. Nestas autorizações a doutrina, sem negar a discricionariedade na emissão, a recusa na revogação antes do fim do prazo. ${ }^{43}$

Alguns autores extraem do sistema da Lei a estabilidade das autorizações petrolíferas. ${ }^{44} \mathrm{~A}$ isto acresceríamos o fato de que, em razão da própria natureza das atividades envolvidas, que demandam altos investimentos, ${ }^{45}$ a precariedade, deve ser de todo excepcional.

Observe-se que a ANP, como não poderia deixar de ser, ao exercer a discricionariedade conferida pela Lei do Petróleo vem configurando as autorizações por ela emitidas como estáveis, vez que ficam sujeitas apenas a algumas hipóteses taxativas e não discricionárias de revogação.

Veja-se, por exemplo, a Portaria $\mathrm{n}^{\circ} 170$, de 26 de novembro de 1998, regulamentadora da construção, a ampliação e a operação de instalações de transporte ou de transferência de petróleo, seus derivados e gás natural, que dispõe: Art. 15 As autorizações de que trata esta Portaria serão revogadas nos seguintes casos: I liquidação ou falência homologada ou decretada; II - requerimento da empresa autorizada; III - descumprimento das obrigações assumidas nesta Portaria e de outras disposições legais aplicáveis. No mesmo sentido dispõem o art. 15 da Portaria $n^{\circ}$ 201/99; o art. 17 da Portaria $n^{\circ}$ 202/99; o art. 16 da Portaria $n^{\circ}$ 203/99, entre outros.

Entendemos que, mesmo no silêncio da legislação aplicável à atividade petrolífera autorizada, a autorização só ficará sujeita à "revogação" (o termo mais apropriado seria cassação pela ausência de discricionariedade e caráter predominantemente punitivo) se o autorizatário não possuir mais as condições objetivas para o exercício da atividade ou se descumprir as normas da ANP, assegurado o contraditório e a ampla defesa.

43 “A fixação de prazo poderá investir o beneficiário do direito subjetivo oponível à Administraçāo, consistente em perdas e danos, em caso de revogação extemporânea" (Maria Sylvia Zanella Di Pietro, Parcerias na Administração Pública, Ed. ATLAS, $2^{a}$ ed., 1997, p. 99).

44 Nota-se ainda que tem sido revisto, tanto doutrinária como legislativamente, o conceito tradicional de autorização como sendo um ato discricionário e precário. Não existindo uma configuração constitucional do instituto da autorizaçāo, nada impede que o Legislador lhe atribua caráter vinculado e não precário, como o fez na Lei Geral de Telecomunicações e na Lei do Petróleo. Aprofundar em Floriano Azevedo Marques Neto, Direito das Telecomunicações e ANATEL, na obra coletiva Direito Administrativo Econômico, coordenada por Carlos Ari Sundfeld, Ed. Malheiros, São Paulo, 2000, p. 313, e em Maria d'Assunção Costa Menezello, Introdução ao Direito do Petróleo e Gás, constante da mesma obra coletiva, p. 383. Carlos Ari Sundfeld observa que "a Lei do Petróleo parece não ter pretendido submeter os autorizatários ao regime de instabilidade, que se afigura incompatível com a política nela expressa. Na base dessa conclusão está o raciocínio de que, se não há garantia de estabilidade e permanência, não poderá, por via de consequiência, haver liberdade de iniciativa e livre competição" (Regime Jurídico do Setor Petrolífero, pp. 394/5, da obra coordenada por Carlos Ari Sundfeld, Direito Administrativo Econômico, Ed. Malheiros, São Paulo, 2000).

45 As autorizações precárias sāo próprias apenas das atividades que exigem baixos investimentos e que podem ser encerradas a qualquer tempo sem maiores prejuízos. 
A nosso ver as autorizações petrolíferas só poderão ser realmente precárias se a atividade por sua própria natureza puder ser encerrada sem maiores prejuízos para o agente econômico, hipótese, há se notar, bastante rara na indústria do petróleo.

\section{$V$ - As relaçōes de sujeição especial no direito do petróleo}

Antes de abordamos de forma específica o poder normativo da ANP no tocante aos seus concessionários e autorizatários (Tópico VI), devemos analisar a relação de sujeição especial a que ambos se subordinam. Ao fazê-lo, destacaremos a maior potestade que a Administração Pública inegavelmente possui nestas relações, mas também buscaremos livrá-las de alguns paradigmas autoritários que às vezes lhes são atribuídos.

Com efeito, as relações de sujeição especial constituem Instituto regulatório comum a uma série de relações do Poder Público com particulares, mas que, todavia, muitas vezes é manejado como artifício de mitigação dos Princípios da Legalidade e da Proporcionalidade, equívoco que deve ser evitado.

As relações de sujeição especial são um dado comum à regulação das atividades privadas de interesse geral e da exploração privada dos serviços públicos e dos monopólios estatais (o mesmo se diria dos servidores públicos, contratados em geral etc.). Nos termos da Teoria de OTTO MAYER, ${ }^{46}$ estas regulações consubstanciam uma "relação de sujeição especial", e não de supremacia geral, exercida apenas mediante o poder de polícia em seu sentido tradicional, pelo qual "a Administração figura no vínculo jurídico como autoridade pública, utilizando-se do seu poder de império, da sua supremacia perante todos os cidadãos, enquanto exercente de uma função pública, voltada a curar os interesses da coletividade". ${ }^{47}$ Nestes casos poder de império geral —, como não há uma relação prévia entre o administrado e a Administração, para a qual o primeiro teria assentido, o Princípio da Legalidade incide com os seus rígidos contornos tradicionais.

"As relações de supremacia especial são relações específicas travadas pela Administração com o particular, que, por meio delas, insere-se material ou juridicamente na esfera da Administração, justificando o manejo, por parte desta, de poderes inerentes à relação. (...) Por meio deles a Administração poderá realizar injunções, estipular obrigações, criar deveres, que sejam necessários ao cumprimento da finalidade a que serve a atividade, restritos, porém, ao âmbito da referida relação, sem, todavia, ofender o cânone da legalidade. Ao contrário, nesta seara temos implícita autorização legal para a criação de outras regras jurídicas necessárias ao desenvolvimento da relação jurídica" ${ }^{48}$, regras que são decorrentes da adesão consensual do

46 Derecho Administrativo Alemán, Ed. De Palma, Buenos Aires, 1982, tomo I, pp. 144-145

47 José Roberto Pimenta Oliveira, A ANEEL e Serviços de Energia Elétrica, na obra coletiva Direito Administrativo Econômico, coordenada por próprio Carlos Ari Sundfeld, Ed. Malheiros, São Paulo, 2000 , pp. 339 a 341.

48 "A consideração da vontade dos particulares como habilitadora de potestades administrativas foi formulada pelos tratadistas da evolução conceitual sofrida por una das instituições chaves do 
particular ao ordenamento setorial em questão através da autorização, da permissão ou da concessão.

A lei e a anuência do particular se somam para conferir amplos poderes regulatórios ao Estado ${ }^{49}$ que não se isenta da necessária observância do Princípio da Proporcionalidade: “A extensão dos direitos fundamentais a todos os cidadãos, como direitos inerentes à própria personalidade, exige que as limitações ao seu exercício, baseadas na "relação de sujeição especial", em que se encontram certas categorias de pessoas, só sejam admissíveis na medida em que resultarem estritamente indispensáveis para o cumprimento da missão ou da função derivada da situação especial". ${ }^{50}$

\section{$V I$ - Extensão e limites dos poderes normativos da ANP}

As normas aplicáveis às atividades petrolíferas são, em uma primeira escala, as constantes da Constituição e da Lei do Petróleo. Em seguida, há os regulamentos presidenciais, do Conselho Nacional de Política Energética e da ANP.

CARLOS ARI SUNDFELD observa que "o papel dos regulamentos presidenciais ficou reduzido, em função da outorga de parte dos poderes normativos à Agência. Mesmo assim, há regulamentos sobre a estruturação e funcionamento da Administração (o Conselho Nacional de Política Energética é objeto do decreto 2.457; e a Agência Nacional do Petróleo do Decreto 2.455, ambos de 1988; o

Direito administrativo: a autorização. Assim, Franchini dizia que "parece claro que o particular, através do ato de autorização vem a renunciar, a fim de ver removida a proibição... a uma parte de sua liberdade. Este ato de submissão voluntária, em geral resulta implicitamente contido na própria solicitação de autorização". Em termos muito semelhantes, Manzanedo escrevia que "a solicitação de autorização tem a ela implícito o consentimento do interessado a esta submissão especial, que é, definitivamente, o preço que paga para consegui-la. (...) Não se trata de uma espécie de negociação entre entidades de crédito (poder-se-ia aludir às concessionárias, permissionárias e autorizatárias em geral) e a Administraçāo, pela qual as primeiras cederiam parte da sua liberdade de empresa. Do que há de se falar propriamente é da configuração do conteúdo de tais direitos individuais pela atuação de poderes administrativos suficientemente habilitados em normas legais, cuja razão última é a garantia do interesse social situado em uma atividade tāo relevante para todo o conjunto de cidadãos" (José María Michavila Núñez, "Relación especial de sujeción" en el sector crediticio y Estado de Derecho, Revista Española de Derecho Administrativo, vol. 54).

49 "As chamadas relações de sujeicão especial não são um âmbito em que os sujeitos ficam despojados dos seus direitos fundamentais ou em que a Administracão possa ditar normas sem habilitacão legal prévia. Estas relações não se dão a margem do direito, mas dentro dele e, portanto, também nelas têm vigência os direitos fundamentais, de forma que a Administração não goza nestas relações de sujeição especial de um poder normativo carente de habilitacão legal, ainda que esta possa ser outorgada em termos que nāo seriam aceitáveis em relações de sujeição geral" (El principio non bis in idem y su aplicación a las relaciones de sujecion especial de la policia gubernativa, STC 234/1991, de 10 de dezembro de 1991, Revista Española de Derecho Administrativo, vol. 79, grifamos)

50 Rafael Gómez-Ferrer Morant, Derecho a la tutela judicial y posición jurídica peculiar de los poderes públicos, Revista Española de Derecho Administrativo, vol. 33. 
procedimento sancionatório da ANP no exercício da regulação é tema do Decreto 2.953, de 1999), sobre as participações financeiras governamentais na exploração do petróleo e gás (Decreto 2.705, de 1988) e sobre a exportação do petróleo, derivados e gás (Decreto 2.705, de 1998).

O mais são portarias da ANP, editadas com o poder normativo para regulação conferido pela Lei do Petróleo e versando assuntos como a licitação de blocos para exploração de petróleo, a construção e operação de refinarias, as instalações de transporte, o direito de uso de gasoduto alheio, e assim por diante". ${ }^{51}$

O poder normativo das agências reguladoras é tema amplo e polêmico em todos os países em que foram implantadas. Porém, a análise do direito comparado demonstra que a polêmica em torno do amplo poder normativo outorgado às agências é diretamente proporcional à aceitação que em todo canto estes poderes possuem pelos mais diversos fundamentos, invariavelmente acrescidos de razões práticas e da própria concepção desta espécie de instituições reguladoras. ${ }^{52}$

Preliminarmente, devemos conceituar o que deve se entender por "regulação", o que, longe de possuir interesse meramente acadêmico, é imprescindível para que seja definida a competência da ANP, ente constitucionalmente qualificado como o "regulador do monopólio da União".

Do conceito de regulação está excluída a atividade direta do Estado como produtor de bens ou serviços e como fomentador das atividades econômicas privadas, ${ }^{53}$ que, junto com a regulação, constituem espécies do gênero da intervenção do Estado na economia. ${ }^{54}$

A noção de regulação implica a integração de diversas funções: pressupõe que um quadro seja imposto às atividades econômicas, devendo respeitar um certo equilíbrio dos interesses das diversas forças sociais presentes. Este quadro normativo é estabelecido por decisões gerais e abstratas, constantes geralmente de regulamentos; pela aplicação concreta das suas regras; e pela composição dos conflitos que delas advém, dando lugar, nestas duas últimas hipóteses, a decisões individuais. ${ }^{55}$ Há, portanto, três poderes inerentes à regulação: aquele de editar a regra, o de assegurar a sua aplicação e o de reprimir as infrações. ${ }^{56}$

51 Regime Juridico do Setor Petrolífero, constante da obra coletiva coordenada por Carlos Ari Sundfeld, Direito Administrativo Econômico, Ed. Malheiros, São Paulo, 2000 p. 386.

52 Por todos, ver Frank Moderne, Etude Comparée, obra coletiva Les Autorités Administratives Indépendantes, coord. Claude-Albert Colliard e Gerard Timsit, Presses Universitaires de France PUF, 1988, pp. 186 a 222

53 Alguns autores chamam esta intervenção de regulação operativa, em contraposição à regulação normativa, aqui por nós denominada simplesmente de regulação (Conrado Hübner Mendes, Reforma do Estado e Agências Reguladoras, constante da obra coletiva Direito Administrativo Econômico, coordenada por Carlos Ari Sundfeld, Ed. Malheiros, São Paulo, 2000, p. 117).

54 Daí se falar hoje na passagem do Estado produtor ao Estado regulador, interventor, no entanto, em ambos os casos.

55 Salvatore Cattaneo, "Agencies" e "Regulation" nel Regno Unido, constante da obra coletiva Le Autorità Indipendenti - De fattori evolutivi ad elementi della transizione nel diritto pubblico italiano, Giuffrè Editore, Milāo, 1999, p. 263. 
Entre todas as competências inerentes à regulação, a que mais gera polêmica é a de estabelecer normas genéricas e abstratas.

$O$ presente trabalho não comportaria uma análise exaustiva do tema, ${ }^{57}$ razão pela qual nos cindiremos aos seus aspectos mais relevantes para o Direito do Petróleo.

Como afirma BERNARD SCHWARTZ, ${ }^{58}$ e ressalvadas as peculiaridades do Direito norte-americano, que aqui não se mostram fundamentais, o traço fundamental das agências administrativas independentes é o fato de possuírem uma combinação das funções de legislador, promotor e juiz. Iniciam processos, de ofício ou quando provocadas, julgando-os segundo as normas por elas próprias estabelecidas.

Em igual sentido, JUAN CARLOS CASSAGNE ${ }^{59}$ observa que os poderes conferidos a estes órgãos e entidades são de "variada natureza e extensão". O panorama é amplíssimo, abrangendo os clássicos poderes administrativos relacionados com a fiscalização das atividades desenvolvidas pelos particulares, cumprimento das regras estabelecidas nos contratos de concessão, nas licenças ou nas autorizações, incluindo o estabelecimento de eventuais tarifas, poderes disciplinares, sancionatórios e preventivos de condutas prejudiciais aos interesses coletivos tutelados etc.

O que se verifica é a transformação dos modelos de administração pública, que passam a se situar no desenho organizativo e na gestão de recursos em função da natureza das tarefas, levando à fragmentação harmônica do aparato administrativo, à necessidade de novos instrumentos de integração e coordenação, e ao reconhecimento de novos graus do exercício autônomo de competências normativas, com a emergência de mecanismos de controle mais finalísticos que hierárquicos. ${ }^{60}$

56 Michel Gentot, Les Autorités Administratives Indépendantes, Ed. Montchrestien, Paris, 1994, $2^{*}$ ed., p. 41 . Na doutrina nacional também se observa que aos órgãos e entidades reguladores "cabe não apenas operacionalizar a regulação contida em lei (normativa), através da competência que lhe é outorgada para fiscalizar e aplicar sançōes, mas também complementar tal corpo normativo com regulamentos próprios, além de possuir competência para também dirimir conflitos" (Conrado Hübner Mendes, Reforma do Estado e Agências Reguladoras, constante da obra coletiva Direito Administrativo Econômico, coordenada por Carlos Ari Sundfeld, Ed. Malheiros, São Paulo, 2000, p. 118, grifamos).

57 Para desenvolvimento do tema, ver o nosso Os Ordenamentos Setoriais e as Agências Reguladoras Independentes, constante da obra coletiva "Direito Político", organizada por Diogo de Figueiredo Moreira Neto, Ed. Lumen Júris/APERJ, Rio de Janeiro, 2000, pp. 87 a 136.

58 American Administrative Law, Sir Isaac Pitman \& Sons Lida., London, 1950, pp. 13 e 14.

59 Los Nuevos Entes Regulatorios, integrante da obra coletiva El Derecho Público Actual, Ediciones Depalma, Buenos Aires, 1994, pp. 45/6.

60 O que importa frisar é que a autonomia ou independência das agências reguladoras não implica em ausência de controles (não hierárquicos), vez que não podem ficar excluídas do planejamento e coordenação do conjunto das ações estatais. Note-se que, mesmo nos Estados Unidos da América do Norte, país no qual as agências reguladoras alcançaram o seu maior grau de autonomia, o Presidente da República editou a Ordem Executiva $n^{\circ} 12.886 / 93$ - Regulatory Planning and Review. Este ato estabelece procedimentos obrigatórios para as agências, no sentido de que, antes de regulamentarem determinada matéria, devem comunicar a sua intenção a um órgão central do Governo - o Regulatory Working Group - incumbido de alertá-las para as regulações desnecessárias, dúplices ou contraditórias entre si ou com a política governamental. Para maiores detalhes, 
É, de fato, importante notar como, "de uma concepção de lei geral e abstrata de tradições liberais oitocentistas a uma legislação de caráter administrativo própria do Estado interventor, se esteja delineando uma tendência à expansão das normatizações setoriais, fruto de um ordenamento policêntrico e pluralista." 61

Disto, não se pode, entretanto, inferir o fim do Estado DE Direito, já que este não se confunde com o Estado legal ou Estado DO Direito. ${ }^{62}$

O Estado legal ou DO Direito consiste apenas no estabelecimento de uma regra de competência atributiva da sobrepujança do Poder Legislativo sobre os demais. $\mathrm{O}$ Estado DE Direito, ao revés, consubstancia-se numa ordem axiológica da sociedade. ${ }^{63}$ "Se o Estado DO Direito se caracteriza essencialmente por suas formas e suas estruturas jurídicas, é, no Estado DE Direito, a participação ideológica que prevalece sobre a arquitetônica jurídica e liga a esperança da liberdade à sua realização" ${ }^{64}$

O que devemos ter realmente em mira, independentemente de qual seja o Poder ou a entidade emanadora, é que as normas jurídicas devem, em qualquer hipótese, atender ao devido processo legal, em suas dimensões adjetivas e substantivas, e visar à realização dos valores constitucionais.

As leis atributivas de poder normativo às entidades reguladoras independentes possuem baixa densidade normativa, a fim de propiciar o desenvolvimento de normas setoriais aptas a, com autonomia e agilidade, regular a complexa e dinâmica realidade social subjacente. Ademais, recomenda-se que propiciem à Administração a possibilidade de, na medida do possível, atuar consensualmente, com alguma margem de negociação, junto aos agentes econômicos e sociais implicados.

Detalhando essa necessidade, GIUSEPPE ABBAMONTE ${ }^{65}$ adverte que, diante de uma realidade de grande complexidade, decorrente da crescente concentração dos centros de poder econômico, se requer ações capazes de identificar e individuar obrigações, acompanhar o seu cumprimento, fixando, inclusive, regras de compor-

remetemos o leitor à obra de Eloísa Carbonell e José Luis Muga, Agencias y Procedimiento Administrativo en Estados Unidos de América, Ed. Marcial Pons, Madrid, 1996, pp. 43 a 47.

61 Paola Bilancia, Attività Normativa delle Autorità Indipendenti e Sistema delle Fonti, constante da obra coletiva Le Autorità Indipendenti: Da fattori evolutivi ad elementi della transizione nel Diritto Pubblico italiano, Giuffrè, Milano, 1999, p. 146 (grifamos).

62 A pedra de cal no ideal legalista do iluminismo de que a lei (do parlamento) seria, por definição, justa, foi a série de iniqüidades cometidas na história (nazismo, fascismo, etc.) através da lei. Nas palavras de Louis Favoreu, é " necessário proteger-se também contra ela e não mais exclusivamente contra os atos do poder executivo; a lei não está mais no centro do sistema normativo" (A Evolução e a Mutação do Direito Constitucional Francês, constante da obra coletiva "Direito Constitucional — Estudos em Homenagem a Manoel Gonçalves Ferreira Filho", Ed. Dialética, 1999, p. 215).

63 Redor Marie-Joëlle, na obra, eloquiente pelo seu próprio título, De l'État légal à l'État de Droit, Ed. Economica, 1992, p. 389.

64 Simone Goyard-Fabre, Os Princípios do Direito Político Moderno, trad. Irene A. Paternot, Ed. Martins Fontes, 1999, p. 322.

65 Trattato di Diritto Amministrativo, dirigido por Giuseppe Santaniello, CEDAM, Padova, 1990, Volume Oitavo, p. 87. 
tamento, inserindo-se na realidade, guiando-a e, possivelmente, corrigindo-a, ou, ao menos, reequilibrando as tendências desestabilizadoras. Deve haver a capacidade de coordenação do público e do privado, de modo a "receber material de primeira mão", calibrar a ação em relação às circunstâncias e, ao mesmo tempo, em relação às possibilidades concernentes aos vários ramos de atividades econômicas, na sequiência do tempo e na diversidade de lugares".

Abordando a matéria, MARCO AURÉLIO GRECO, ${ }^{66} \mathrm{em}$ debate realizado na Federação das Indústrias do Estado de São Paulo - FIESP, indagou: "Será que numa interpretação do direito positivo nós não deveríamos interpretar legalidade com eficiência, e, óbvio, eficiência com legalidade? Mas em que a legalidade deixa de ser um desenho formal para ser um instrumento funcional de obtenção de resultados, de atingimento de objetivos? E talvez dentro deste contexto e a partir deste desenho é que nasceriam essas agências, com reflexos, automaticamente, no seu poder regulamentar, que em certa medida, acredito que até extravasa a figura do regulamento clássico."

Com efeito, devemos observar que o Poder Legislativo, face à complexidade, dinamismo e tecnicização da sociedade, tem distinguido os aspectos políticos dos de natureza preponderantemente técnica da regulação social, retendo os primeiros, mas, consciente das suas naturais limitações, transpassando a outros órgãos ou entidades, públicas ou privadas, a normatização de cunho marcadamente técnico. Porém, mesmo nestes casos resguarda o Poder Legislativo o balizamento e a coordenação destas regulações plurifórmicas e pluricêntricas. ${ }^{67}$

A necessidade de descentralização normativa, principalmente de natureza técnica, é a razão de ser das entidades reguladoras independentes, ao que podemos acrescer o fato da competência normativa, abstrata ou concreta, integrar o próprio conceito de regulação.

66 Excerto dos debates realizados na reunião do Conselho Superior de Assuntos Jurídicos e Legislativos (CONJUR), realizada em 30 de março de 2000, na sede da FIESP/CIESP, sob o tema "Reforma do Estado: O papel da agências reguladoras e fiscalizadoras", constante do Caderno de Debates $n^{\circ} 18$ do Instituto Roberto Simonsen-IRS, p. 39.

67 Merece transcrição o seguinte excerto de Manoel Gonçalves Ferreira Filho, no qual o autor, com maestria, distingue as leis que devem permanecer no âmbito do Legislativo, e as que, pela natureza, devem ser por este confiadas a sedes normativas nāo parlamentares: "Não sendo necessária a vinculação entre democracia e legislação parlamentar, é possível e mesmo urgente que novos rumos sejam experimentados no campo da elaboração legislativa. Tais experiências não poderão, 'de per si', ainda que amesquinhem a participação das câmaras nesta tarefa, ser recusadas por antidemocráticas, desde que atendam os valores fundamentais da liberdade $e$ igualdade. Por outro lado, é preciso ter presente que nenhum regime político deve olvidar a eficiência como um dos critérios, e não dos menores, por que sua ação há de se pautar. (...) As leis instrumentais se inscrevem como meios para a realização de objetivos determinados, aprovados pelo próprio povo. Nesse contexto, se quem quer o fim, quer os meios, é mister que, permitindo-se ao povo o estabelecimento das metas, deixe-se ao governo a escolha do instrumental necessário para a sua efetivação" (Do Processo Legislativo, Ed. Saraiva, 3 ed., 1995, pp. 268/9, grifamos). 
A Lei do Petróleo, portanto, sem dar início de per se a uma normatização mais completa, e, muito menos, exaustiva da matéria, estabelece parâmetros e objetivos gerais da regulamentação a ser feita pela ANP, que deverá buscar "preservar o interesse nacional" (art. $1^{\circ}, 1$ ), "valorizar os recursos energéticos" (art. 1", II), "promover a livre concorrência" (art. $1^{\circ}, \mathrm{IX}$ ), "atrair investimentos" (art. $1^{\circ}, \mathrm{X}$ ), "ampliar a competitividade do país" (art. $1^{\circ}, \mathrm{XI}$ ), "promover o aproveitamento racional dos recursos energéticos do País" (art. $2^{\circ}, \mathrm{I}$ ), "assegurar o suprimento de insumos energéticos" (arts. $2^{\circ}$, II e $8^{\circ}, \mathrm{I}$ ), proteger "os interesses dos consumidores" (art. $8^{\circ}, \mathrm{I}$, in fine) etc.

A Lei do Petróleo, portanto, a exemplo das demais leis instituidoras de agências reguladoras, integra a categoria das leis-quadro (lois-cadre) ou standartizadas, próprias das matérias de particular complexidade técnica e dos setores suscetiveis a constantes mudanças econômicas e tecnológicas.

As leis com estas características não dão maiores elementos pelos quais o administrador deva pautar a sua atuação concreta ou regulamentar, referindo-se genericamente a valores morais, políticos e econômicos existentes no seio da sociedade (saúde pública, utilidade pública, suprimento do mercado interno, boas práticas da indústria, competição no mercado, preços abusivos, continuidade dos serviços públicos, regionalização etc.). Assim, confere à Administração Pública um grande poder de integração do conteúdo da vontade do legislador, dentro dos quadros por ele estabelecidos. O objetivo das leis assim formuladas é "introduzir uma vagueza que permita o trato de fenômenos sociais, muito fugazes para se prestarem ao aprisionamento em uma regra precisa." 68

Destaque-se, que a referência aos "quadros estabelecidos pela lei", não concerne apenas a determinado diploma legislativo, mas ao conjunto do ordenamento jurídico. É este que, explícita ou implicitamente, em seu sistema, confere às agências independentes poder regulamentar sobre determinada matéria, não nos sendo dado ficar presos apenas à letra da lei. ${ }^{69}$

Com isto, não estamos "forçando" o conteúdo da Constituição, mas apenas aplicando o principio dos "implied powers", concebido por MARSHALL nos seguintes termos: ${ }^{70}$ "Legítimo o fim e, dentro da esfera da Constituição, todos os meios que sejam convenientes, que plenamente se adaptem a este fim e que não estejam proibidos, mas que sejam compatíveis com a letra e o espírito da Constituição, são constitucionais."

68 Danièle Bourcier, La Décision Artificielle, PUF, 1995, p. 61. Maurice Hauriou destaca a grande importância desta técnica legislativa no Direito Administrativo, vez que " $o$ standard, flexível $e$ mutável, representa no direito o elemento de mobilidade" (Aux Sources du Droit, Librarie Bloud \& Gay, Paris, 1993, pp. 150/1, grifamos).

69 A respeito da pobreza da interpretação meramente literal vale a pena citar a espirituosa passagem de voto proferido pelo Min. Luiz Galloti: "De todas, a interpretação literal é a pior. Foi por ela que Cléia, na Chartreuse de Parme, de Stendhal, havendo feito um voto a Nossa Senhora de que não mais veria seu amante Fabrício, passou a recebê-lo na mais absoluta escuridão, supondo que assim estaria cumprindo o compromisso" (apud Luís Roberto Barroso, Interpretação e Aplicação da Constituição, Ed. Saraiva, 1996, p. 120).

70 Apud Rodolfo Bledel, in Introducción al Estudio del Derecho Publico Anglosajón, Editorial Depalma, Buenos Aires, 1947, p. 57. 
Note-se que a posição ora defendida em relação ao poder regulamentar das agências reguladoras é, há muito, mesmo antes da previsão constitucional de órgãos reguladores específicos, referendada pelos nossos Tribunais.

Pela sua pertinência com o Direito do Petróleo, podemos trazer à baila como exemplo o seguinte excerto de decisão do Superior Tribunal de Justiça - STJ, na qual o MINISTRO HUMBERTO GOMES DE BARROS afirmou a possibilidade da Administração Pública, para alcançar as finalidades genéricas da disciplina da matéria, mas sem qualquer autorização legal específica, restringir a liberdade dos postos adquirirem combustíveis:

“A Constituição Federal, em seu art. 170, preceitua que a ordem econômica é fundada na valorização do trabalho humano e na livre iniciativa, tendo por finalidade assegurar a todos a existência digna, conforme os princípios que enuncia.

No seu art. 174 pontifica que, como agente normativo, e regulador $\mathrm{d}$ i. atividade econômica, o Estado exercerá, na forma da lei, as funções ć. fiscalização, incentivo e planejamento.

Desses dispositivos resulta claro que o estado pode atuar como agente regulador das atividades econômicas em geral, sobretudo das que cuidam as empresas que atuam em um setor absolutamente estratégico, dai lhe ser lícito estipular preços que devem ser por elas praticados.

Montado nestes argumentos, não tenho dúvida em afirmar que o senhor Ministro dispõe de autoridade para impedir que o granelista venda combustível ao varejista ligado a bandeira que não é a sua.

Como registrei acima, controlar a execução de determinada norma é fazer com que ela se desenvolva em busca dos fins sociais para a qual a regra foi concebida.

Os preceitos que disciplinam a distribuição de combustíveis tem como finalidade fazer com que os usuários de tais produtos recebam, com segurança e facilidade, produtos de boa qualidade. Isto ocorre, porque, a exibição do logotipo de marca famosa traduz a afirmação de que no local se vende daquela marca.

Ora, se o posto negocia produtos cuja origem não corresponda à sua bandeira, ele estará enganando o freguês (...).

Quando o freguês é iludido, a distribuição de combustível não estará correspondendo aos fins sociais que orientam as normas disciplinadoras da distribuição de combustíveis". .1 $^{1}$

71 MS 4.578/DF (grifos nossos). 
Colocadas as premissas que comportaram a desmistificação do conceito oitocentista de legalidade, passemos a analisar especifica e detalhadamente os poderes normativos outorgados pelo art. $177, \S 2^{\circ}$, III da Constituição Federal e pela Lei do Petróleo à ANP.

Para melhor disposição metodológica da matéria, optamos por expô-la mediante itens descritivos do poder normativo da ANP, seja em relação às suas potencialidades, seja no que toca aos limites que deve observar. Vejamos:

1. A ANP deve, ao elaborar editais de licitação e contratos de concessão para a exploração e produção de petróleo, atender aos objetivos cuja realização lhe é atribuída pela Lei do Petróleo e pelo Conselho Nacional de Política Energética (arts. $1^{\circ}, 2^{\circ}$ e $8^{\circ}$, Inciso I, da Lei do Petróleo). Ao estabelecer estas normas editalícias e contratuais a ANP estará sempre sujeita às normas constitucionais, legais e regulamentares pertinentes. As normas regulamentares poderão ser revogadas quando forem de sua competência, mas não poderão ser descumpridas em casos concretos enquanto a revogação não se efetivar.

2. Na determinação dos meios para a realização dos fins da Lei do Petróleo e da Política Nacional do setor (ex.: art. $8^{\circ}$, incisos I, IX e X), a Agência possui, via de regra, ampla margem de discricionariedade, não só para a emissão de normas gerais e abstratas, como para a fixação das cláusulas dos contratos de concessão e dos termos das autorizações.

3. A margem de normatização da Agência descrita no item anterior é, no entanto, menor nos casos em que a própria Lei houver pré-determinado os meios (leia-se, as normas e cláusulas) das quais deverá se valer para atendimento dos objetivos nela fixados.

É o que se dá em relação às concessões, para as quais a Lei do Petróleo estabelece de per se uma disciplina mais clara, diversamente do que ocorre com as autorizações, cuja disciplina legal é bastante avara, o que dá à Agência um campo de regulação especialmente amplo sobre as atividades autorizadas.

4. Muitas vezes a própria Lei expressamente remete a matéria à regulamentação da ANP (ex.: arts. $8^{\circ}, \mathrm{III}, \mathrm{V}$, in fine, VI, XV; $9^{\circ} ; 29$, in fine; $53, \S 1^{\circ} ; 56$, Parágrafo único).

Todavia, como visto na decisão do STJ acima citada, o fato da Lei remeter expressamente determinadas matérias às normas da Agência, não ilide os amplos poderes normativos que podem existir em matérias não especificadas e não exaustivamente disciplinadas pela Lei.

5. Uma vez celebrada concessão, a Agência permanece com o poder de emitir normas genéricas e abstratas a respeito das atividades de exploração e produção de petróleo. Em regra estas normas deverão se desenvolver apenas no espaço de normatização/integração deixado pelos próprios contratos de concessão através de lacunas, de remissões à regulamentação da ANP ou da utilização de conceitos jurídicos indeterminados (ex.: as boas práticas da indústria do petróleo), que podem ser densificados pela Agência sempre na senda da persecução da política pública traçada para o setor pela Lei e pelo Conselho Nacional de Política Energética. 
6. Mais controvertida é a possibilidade da ANP poder editar normas que contrariem o contrato de concessão. Entendemos que as cláusulas do contrato que forem oriundas diretamente da Lei (por exemplo, as previstas no art. 44 da Lei do Petróleo) não podem ser atingidas por normas regulamentares anteriores ou posteriores. Mas as cláusulas que advieram tão-somente do poder regulatório da ANP de elaboração dos editais e das minutas de contrato (art. $8^{\circ}$, IV) poderão, dentro do princípio do trial and error das políticas públicas, ser proporcional, motivada e razoavelmente adequadas às contingências, sempre observados os objetivos fixados pela Lei e pelo Conselho Nacional de Política Energética. Tanto é assim, que o art. 19 da Lei do Petróleo estabelece o procedimento que deve preceder à edição de "normas administrativas que impliquem afetação de direitos dos agentes econômicos".

Com efeito, o Estado atua "no esforço constante de controlar as consequiências de suas acções a fim de as corrigir a tempo. Portanto, "avançará apenas passo a passo e sempre comparará cuidadosamente os resultados perspectivados com os realmente alcançados, estando continuamente atento aos efeitos secundários indesejáveis". ${ }^{72}$

Como visto no Tópico III, a natureza privada das concessões petrolíferas em nada ilide este poder da ANP, que, no entanto, deve ser exercido com grande parcimônia e rígida sindicabilidade ao Princípio da Proporcionalidade, assegurada sempre a indenização ou recomposição da estrutura contratual, não em virtude de uma incabível analogia com o equilibrio econômico-financeiro das concessões de serviços públicos, mas como aplicação da Teoria Geral da Imprevisão por fato príncipe ou fato da Administração. ${ }^{73}$

7. Em relação às autorizações a ANP tem amplo poder de normatização ao longo do desenvolvimento das atividades autorizadas, conformando-as permanentemente aos objetivos da política pública do setor. Isto decorre, não apenas do laconismo da Lei na matéria, como também da própria natureza - funcional e operativa - destas autorizações (cf. Tópico IV). Ressalva-se, contudo, que a imposição de obrigações às empresas autorizatárias não podem chegar ao ponto de inviabilizar tout court a atividade, com o que estaria a ANP, por via indireta, transformando a autorização petrolífera em ato precário (cf. Tópico IV, in fine).

8. O art. 19 da Lei do Petróleo impõe a obrigatoriedade da realização de prévia audiência pública pela ANP a respeito das normas que pretenda emitir que possam afetar direitos dos agentes econômicos, dos consumidores e usuários de bens e serviços da indústria do petróleo, tal como definida no inciso XIX do art. $5^{\circ}$.

Note-se que esta exigência procedimental, longe de ser mera formalidade, é requisito da validade das normas a serem editadas, e impõe não apenas a mera realização da audiência, como, em virtude do Princípio da Motivação, a apreciação,

72 Reinhold Zippelius, Teoria Geral do Estado, Fundação Calouste Gulbenkian, 3' ed., 1997, trad. Karin Praefke-Aires Coutinho, Coordenação de J. J. Gomes Canotilho, pp. 469 e 470.

73 O fato príncipe é a determinação geral e imprevisível da própria Administração contratante. Já o fato da Administração não é geral, é ação ou omissão da Administração, que atinge concreta e diretamente o próprio contrato. 
e se for o caso, a recusa justificada, de todas as críticas e sugestões formuladas doutrina do hard look. ${ }^{74}$

O que a Lei do Petróleo objetiva com a exigência de audiências públicas é suprir o déficit democrático co-natural a todas as agências reguladoras que, além de amplos poderes normativos, têm os seus dirigentes resguardados da livre exoneração pelos titulares de poder político democraticamente eleitos (art. $9^{\circ}$, Lei $n^{\circ} 9.986 / 2000$ ).

A Administrativização da regulação social, a sua crescente tecnicidade, que a coloca não mais diretamente vinculada aos juízos de natureza preponderantemente política, assim como a perda de densidade das leis, que têm a sua força normativa postergada para o momento da sua concretização, ${ }^{75} \mathrm{se}$, por um lado, colocaram em cheque os mecanismos de legitimação tradicionais, típicos do Estado liberal-burguês, por outro, impôs ao Estado e aos seus órgãos de regulação a emergência de novos modos de legitimação.

Em primeiro lugar não devemos olvidar que a regulação estatal é hodiernamente direcionada pelos objetivos fixados nas leis e na Constituição. Neste contexto, muito mais do que aferir a legitimidade da regulação pela sua subsunção lógico-formal à determinado preceito legislativo, deve ser verificado o atendimento das finalidade públicas a que se destina. Ao esquema, não mais exclusivo, de preceito-sanção, devemos agregar o de objetivo-meio eficaz. ${ }^{76}$

Em segundo lugar, como legitimação do processo decisório, devem ser adotadas medidas capazes de suprir o déficit de democraticidade da regulação administrativa, criando um "espaço público de discussão", 77 inclusive, tal como preconizado pela Lei do Petróleo (art. 19), mediante a participação pública na edição dos atos normativos, e a obrigação da Administração, ao expedir o regulamento, motivar as recusas às sugestões e críticas da coletividade.

74 Juan José Lavilla Rubira, La Participación Pública en el Procedimiento de Elaboración de los Reglamentos en los Estados Unidos de América, Ed. Civitas, Madrid, 1991, pp. 142 a 146.

75 "A autonomia crescente do executivo perante a lei coloca-lhe contudo o problema espinhoso da legitimação da sua ação; é que esta, por ser cada vez mais independente da lei não pode esperar dela a legitimação democrática que decorre do facto de a lei representar autenticamente a opinião pública dominante. Por outro lado a legitimação que para a actividade administrativa poderia derivar da sua fiscalização parlamentar depara igualmente com limites intransponíveis, dado que grande parte da moderna acção administrativa no domínio econômico é levada a cabo por entidades públicas, privadas ou mistas dotadas para tanto de meios próprios independentes relativamente ao governo, o que dificulta o controle político parlamentar pois que nāo é possível invocar os meios da subordinação hierárquica e da centralização administrativa para responsabilizar o governo pela acção desenvolvida" (Luis S. Cabral de Moncada, Direito Económico, Coimbra Editora, $2^{\mathbf{2}}$ ed., 1988, p. 42).

76 Charles-Albert Morand, Le Droit Néo-Moderne des Politiques Publiques, LGDJ, Paris, 1999, pp. 101/2.

77 Charles-Albert Morand, Le Droit Néo-Moderne des Politiques Publiques, LGDJ, Paris, 1999, p. 103. O autor suíço cita como exemplo, uma decisão do Tribunal Federal do seu país: "A idéia de compensar a faita de densidade normativa pela participação não é ausente na jurisprudência. $O$ Tribunal Federal, assim, por exemplo, considerou que, em virtude da fraca densidade normativa da regulamentação de prevenção de catástrofes, a Administração deveria instaurar um diálogo com as empresas a fim de determinar em comum as medidas a serem tomadas" (p. cit.). 
Mister se faz advertir apenas que a participação pública no processo regulatório (decision-making process) se reporta essencialmente à sua fase preparatória, não retirando da administração a última palavra na matéria, ${ }^{78}$ desde que o faça motivadamente e dentro dos quadros estabelecidos pela lei.

Devemos também advertir que a Lei do Petróleo impõe a realização de audiências públicas apenas para a edição de normas que possam afetar direitos, não meros interesses, ressalvada, no entanto a faculdade da ANP, sempre que a matéria for de interesse geral, submetê-la à consulta pública, tal como disposto no art. 31 da Lei do Processo Administrativo Federal, Lei $n^{\circ}$ 9.784/99.

Condensando o exposto neste Tópico, podemos afirmar que o poder normativo da ANP deverá, malgrado a sua inegável amplitude, se basear nos princípios do Estado Democrático de Direito e da Administração Pública, notadamente nos princípios da razoabilidade e da eficiência, restringindo os direitos e interesses, individuais ou coletivos, apenas na medida em que a restrição for capaz de atingir com eficiência os fins públicos legitimamente almejados. "Trata-se de uma tarefa que, todos os dias se coloca de novo, e de uma arte política que consiste em procurar continuamente uma relação óptima entre a proporção imprescindível de regulamentação estatal, por um lado, e auto-regulação e autodesenvolvimento, "autônomos", por outro. A análise teórica não pode mais do que tentar tornar as conexões mais transparentes. No entanto, não pode resolver a tarefa da política de encontrar a medida justa em função das situações concretas alternantes e de regular convenientemente o estado de coisas". ${ }^{79}$

\section{VII - Conclusōes}

O Direito do Petróleo demonstra como poucos outros ramos do Direito a necessidade de equilibrada composição da dialética existente entre as esferas pública e privada; entre o interesse público e os interesses privados; regulação estatal e livre iniciativa; nacionalismo e mercado globalizado; entre a necessidade de preservação e a emergência da expansão.

A solução dos problemas inerentes ao Direito do Petróleo pressupõe o permanente recurso à proporcionalidade entre os valores envolvidos, vez que a preponderância a priori de qualquer um deles, por parcial, estará fadada ao insucesso.

Como aconselhado por PONTES DE MIRANDA, "é difícil ao jurista de direito público, principalmente do político, livrar da influência do caso concreto, histórico,

78 Luis S. Cabral de Moncada observa que "a concertação das decisões administrativas modificou o processo de formação respectiva, mas não as afectou na sua estrutura de decisões unilaterais. Assim sendo manteve-se quase sempre inalterado o modelo tradicional (unilateral) da actuação administrativa, muito embora a respectiva orgánica tenha se modificado radicalmente" (Direito Económico, Coimbra Editora, $2^{\star}$ ed., 1988, p. 43).

79 Reinhold Zippelius, Teoria Geral do Estado, Fundação Calouste Gulbenkian, 3’ ed., 1997, trad. Karin Praefke-Aires Coutinho, Coordenação de J. J. Gomes Canotilho, p. 475. 
que o cerca, o seu pensamento teórico. Só a preço de grande disciplina mental tal libertação é possível; mas essa libertação é indispensável, tratando-se de cientista" ${ }^{80}$

Foi no esforço de nos mantermos dentro destes lindes metodológicos que buscamos colaborar para a solução de alguns dos desafios colocados aos teóricos e operadores que atuam com o Direito do Petróleo.

Após analisadas as linhas gerais da disciplina constitucional e legal do petróleo, a natureza jurídica das suas concessões e autorizações e os contornos do poder normativo da Agência Nacional do Petróleo - ANP, podemos chegar às seguintes conclusões:

- A liberalização pela qual passa a indústria do petróleo, exige do jurista criatividade para elaborar teoricamente os novos fenômenos normativos e institutos positivados em nossa legislação constitucional e infra-constitucional;

- A indústria do petróleo envolve atividade econômica monopolizada pelo Estado, não serviço público;

- A exploração, produção, refino, importação, exportação e o transporte marítimo ou por dutos de petróleo ou derivados constituem monopólio da União, ao passo que as demais modalidades de transporte, a distribuição e a revenda são atividades privadas, sujeitas, no entanto, à regulação estatal;

- A exploração e a produção podem ser desenvolvidas por particulares mediante concessão e as demais atividades através de autorização;

- As concessões petrolíferas são contratos de direito privado - não são concessões de serviços públicos -, o que não ilide, porém, a possibilidade de regulação estatal sobre a sua celebração e execução;

- As autorizações petrolíferas são da espécie operativa ou funcional, que pressupõem uma constante conformação à política pública estabelecida para o setor;

- A relação de sujeição especial que envolve os agentes econômicos da indústria do petróleo não lhes retira as garantias da legalidade e proporcionalidade da regulação estatal, ressalvadas as peculiaridades oriundas do seu prévio assentimento, manifestado com a celebração dos contratos de concessão ou pela solicitação das autorizações;

- Ultrapassada a feição oitocentista do Princípio da Legalidade, ele deve ser entendido como assecuratório de uma atuação administrativa eficiente, proporcional e jungida aos fins legais;

- A ANP é dotada de poder normativo para implementar a política estabelecida para o setor petroleiro pela Lei do Petróleo e pelo Conselho Nacional de Política Energética, observadas as normas legais específicas eventualmente existentes e o direito de recomposição econômica dos agentes econômicos que tenham os seus direitos (não meros interesses) atingidos; e

- Nos casos em que exigida pela Lei do Petróleo, a audiência pública constitui requisito essencial para a validade das normas da ANP. 